\title{
Seasonal Changes in Spermatogenesis and Immunolocalization of Inhibin/Activin Subunits in the Wild Male Ground Squirrel (Citellus dauricus Brandt)
}

\author{
Xia SHENG ${ }^{1)}$, Haolin ZHANG ${ }^{1}$, Wei ZHANG ${ }^{1)}$, Moshi SONG ${ }^{1)}$ Mengyuan ZHANG ${ }^{1}$, \\ Ben LI ${ }^{1)}$, Qiang WENG ${ }^{1,2)}$, Gen WATANABE ${ }^{2,3}$ and Kazuyoshi TAYA ${ }^{2,3)}$ \\ ${ }^{1)}$ College of Biological Science and Technology, Beijing Forestry University, Beijing 100083, China, ${ }^{2)}$ Laboratory of \\ Veterinary Physiology, Department of Veterinary Medicine, Faculty of Agriculture, Tokyo University of Agriculture and \\ Technology, Tokyo 183-8509 and ${ }^{3)}$ Department of Basic Science, United Graduate School of Veterinary Sciences, Gifu \\ University, Gifu 501-1193, Japan
}

\begin{abstract}
The objective of this study was to investigate the seasonal changes in spermatogenesis and the immunolocalization of the inhibin $\alpha$ and inhibin/activin $\left(\beta_{\mathrm{A}}\right.$ and $\left.\beta_{\mathrm{B}}\right)$ subunits during the breeding and non-breeding seasons in the wild male ground squirrel. The testicular weight and size and seminiferous tubule diameter were measured, and histological observations of testes were performed. The sections of the testes were immunostained by the avidin-biotin-peroxidase complex method (ABC) using polyclonal antisera raised against porcine inhibin $\alpha$, inhibin/activin $\beta_{\mathrm{A}}$ and inhibin/activin $\beta_{\mathrm{B}}$ during the breeding and non-breeding seasons. There were marked variations in testicular weight and size and seminiferous tubule diameter between the breeding and non-breeding seasons, and all types of spermatogenic cells, including spermatozoa, were found in the breeding season. In addition, immunoreactivity was also detected for the inhibin $\alpha, \beta_{\mathrm{A}}$ and $\beta_{\mathrm{B}}$ subunits in Sertoli and Leydig cells during the breeding season, but immunostaining was only present for the inhibin $\alpha$ and inhibin/activin $\beta_{\mathrm{B}}$ subunits in Sertoli cells during the non-breeding season. These results suggest that seasonal changes in testicular weight and size and seminiferous tubule diameter of wild ground squirrels are correlated with changes in spermatogenesis, and the cellular localization of the inhibin/activin subunits showed season related changes in the breeding and non-breeding seasons.
\end{abstract}

Key words: Ground squirrel (Citellus dauricus Brandt), Immunohistochemistry, Inhibin, Spermatogenesis, Testis

(J. Reprod. Dev. 54: 460-464, 2008)

$\mathbf{T}$ he inhibin/activin subunits are members of the transforming growth factor $\beta$ (TGF $\beta$ ) superfamily. They are produced in the testes and are postulated to have paracrine and autocrine roles in the regulation of steroidogenesis and spermatogenesis in addition to endocrine regulatory effects on FSH secretion [1-4]. Inhibin consists of an $\alpha$ subunit linked by a disulfide bridge to one of the 2 highly homologous $\beta$ subunits $\left(\beta_{\mathrm{A}}\right.$ and $\beta_{\mathrm{B}}$ ) to form inhibin $\mathrm{A}\left(\alpha\right.$ and $\beta_{\mathrm{A}}$ ) or inhibin $\mathrm{B}$ ( $\alpha$ and $\beta_{\mathrm{B}}$ ) [5]. In the male, inhibin is produced in the testis, principally by Sertoli cells. The various inhibin/activin subunits have been localized in testes as messenger RNA and proteins. The expression of mRNA in Sertoli cells varies with the stage of the seminiferous cycle [6], with differences between the various subunits possibly reflecting differential production of activin and inhibin [7]. Some seasonal male breeders, such as stallions [5, 8, 9], rams [10] and Japanese monkeys [1113], show seasonal changes in circulating inhibin concentrations in accordance with testicular activity. Furthermore, in Japanese black bears [14] and raccoon dogs [15], there are temporal changes in inhibin expression and secretion with the changing role of Sertoli cells in the breeding and non-breeding seasons.

The wild male ground squirrel (Citellus dauricus Brandt) is a typical seasonal breeder with a short sexually active period in April

Accepted for publication: August 26, 2008

Published online in J-STAGE: September 26, 2008

Correspondence: Q Weng (e-mail: weng3@msn.com) and May followed by a long period of sexual dormancy from June to March. Studies of ground squirrels have shown that they are active for about six months in late spring, summer and early fall and that they hibernate during the remainder of the year [16]. The breeding season of the ground squirrel begins soon after emergence from hibernation [17]. Although several observations about reproduction in ground squirrels have been reported recently [16-18], there are still many gaps in understanding of the mechanisms of reproduction, especially secretion of inhibin in the testicular recrudescence and regression process. The aim of the present study was to investigate the localization of the inhibin/activin subunits in testes during the breeding and non-breeding seasons and to elucidate the relationship between inhibin and reproductive function in wild male ground squirrels.

\section{Materials and Methods}

\section{Animals}

Sixteen wild male ground squirrels that were thought to be adult based on their body weights (242-412 g) were captured in May (breeding season) and September (non-breeding season) of 2007 in Hebei Province, China (Fig. 1a and b). Testicular weight was measured using scales, and testicular size was expressed in mm after measurement (length $\times$ width $\times$ height $)^{1 / 3}$ following necropsy. The obtained testicular tissues were immediately fixed in $4 \%$ paraform- 

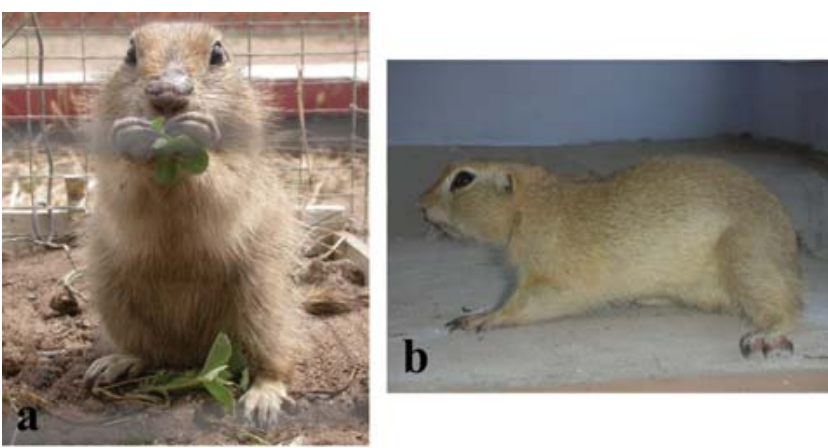

Fig. 1. A male ground squirrel (Citellus dauricus Brandt; a and b).

aldehyde (Sigma-Aldrich Chemical, St. Louis, MO, USA) in 0.05 M PBS (pH 7.4) for histological and immunohistochemical observations.

\section{Histology}

Testicular samples were dehydrated in ethanol series and embedded in paraffin wax. Serial sections $(4 \mu \mathrm{m})$ were mounted on slides coated with poly-L-lysine (Sigma). Some sections were stained with hematoxylin-eosin (HE) for observations of general histology. Ten seminiferous tubules per ground squirrel were evaluated histologically using an Olympus photomicroscope with $\mathrm{a} \times$ 40 objective lens. A movable cursor dot (approximately $0.1 \mu \mathrm{m}$ in diameter) was used for measuring the diameter of the seminiferous tubule. Image Analysis software (Jandel Scientific Sigma Scan ${ }^{\circledR}$; Jandel Scientific, Montgomeryville, PA, USA) was used for processing measurements.

\section{Immunohistochemistry}

The serial sections of testes were incubated with $10 \%$ normal goat serum to reduce background staining caused by the second antibody. The sections were then incubated with primary antibody (1:1000 or $1: 2000)$ raised against porcine inhibin $\alpha$ chain (1-30)$\mathrm{NH}_{2}$ conjugated to rabbit serum albumin, porcine inhibin/activin $\beta_{\mathrm{A}}$ (81-113)- $\mathrm{NH}_{2}$ (\#334-274-ET) [19] and cyclic acetyl human inhibin/activin $\beta_{\mathrm{B}}$ (80-112)- $\mathrm{NH}_{2}$ (\#305-25-D) [19] for $12 \mathrm{~h}$ at room temperature. The inhibin $\alpha$ subunit peptide was kindly provided by Dr. N. Ling (Neuroendocrine, San Diego, CA, USA). The antibodies of inhibin/activin ( $\beta_{\mathrm{A}}$ and $\beta_{\mathrm{B}}$ ) were kindly provided by Dr. W. Vale (Salk Institute for Biological Studies, La Jolla, CA, USA). The sections were then incubated with a second antibody, goat antirabbit lgG conjugated with biotin and peroxidase with avidin, using a rabbit ExtrAvidin ${ }^{\mathrm{TM}}$ staining kit (Sigma) and subsequently visualized with $30 \mathrm{mg}$ 3,3-diaminobenzidine (Wako, Osaka, Japan) solution in $150 \mathrm{ml}$ of $0.05 \mathrm{M}$ Tris-HCl buffer (pH 7.6) plus $30 \mu \mathrm{l}$ $\mathrm{H}_{2} \mathrm{O}_{2}$. Finally, the reacted sections were counterstained with hematoxylin solution (Merck, Darmastadt, Germany). The control sections were treated with normal rabbit serum (Sigma) instead of the primary antisera.

\section{Statistical analysis}

Mean values $( \pm \mathrm{SE}$ ) were calculated and analyzed using 1-way
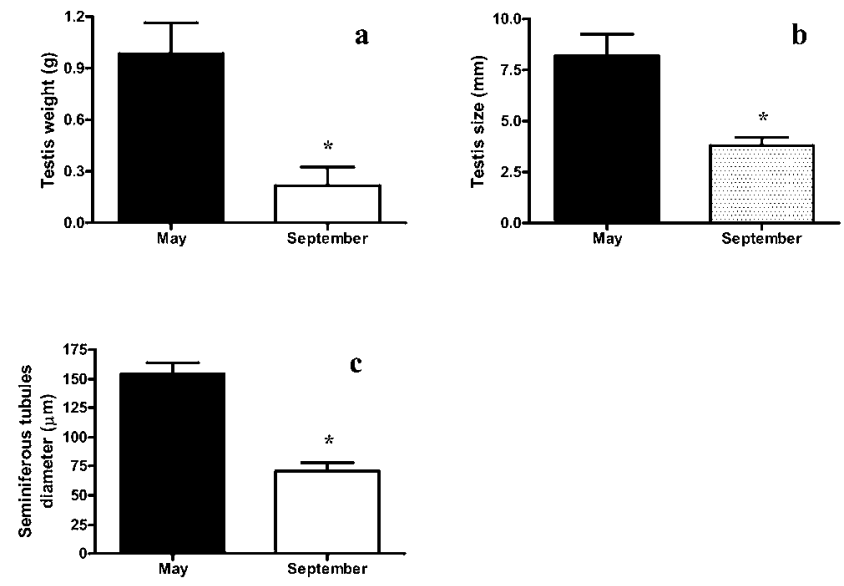

Fig. 2. Seasonal changes in testicular weight (a) and size (b) and seminiferous tubule diameter (c) in wild male ground squirrels. Asterisks $(*)$ indicate significantly differences $(\mathrm{P}<0.01)$. Each bar represents the mean \pm SE of 8 ground squirrels per group.

ANOVA. Duncan's multiple-range test was used for detection of significant differences using the SAS computer package [20].

\section{Results}

\section{Testicular size and weight}

Seasonal changes in testicular weight and size in wild male ground squirrels are shown in Fig. 2 a and b. There were significant $(\mathrm{P}<0.01)$ seasonal changes in testicular weight and size between the breeding season in May (testicular weight, $0.988 \pm$ $0.18 \mathrm{~g}$; testicular size, $8.2 \pm 1.06 \mathrm{~mm}$ ) and the non-breeding season in September (testicular weight, $0.22 \pm 0.1 \mathrm{~g}$; testicular size, $3.82 \pm$ $0.38 \mathrm{~mm})$.

\section{Seminiferous tubule diameter}

There were seasonal changes in the diameters of the seminiferous tubules of the wild male ground squirrels (Fig. 2c). The diameters were significantly higher in the breeding season (150.56 $\pm 9.12 \mu \mathrm{m})$ compared with the non-breeding season (71.4 \pm 6.8 $\mu \mathrm{m})$.

\section{Histology}

Marked seasonal changes were observed in the histological appearance of the seminiferous epithelium in the breeding season and non-breeding seasons. Spermatogenesis also changed seasonally during this period (Fig. 3). A number of seminiferous tubules and the interstitial connective tissue were observed for the testes examined. In the breeding season during May, the most prominent cells in the interstitium were Leydig cells, and the entire spermatogenic cell population from spermatogonia to spermatozoa was present in the seminiferous tubules (Fig. 3a). In the non-breeding season during September, there were a few undifferentiated interstitial cells between the seminiferous tubules, and spermatogonia and spermatocytes were found in the seminiferous tubules (Fig. 3b). 


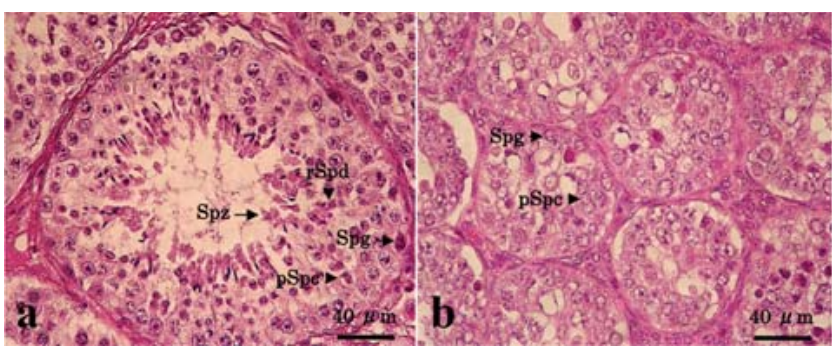

Fig. 3. Seasonal changes in the seminiferous epithelium in wild male ground squirrel testes. a: In May, the entire spermatogenic population, from spermatogonia (Spg) to spermatozoa (Spz), was observed. b: In September, spermatogonia (Spg) and primary spermatocytes $(\mathrm{pSpc})$ were present in seminiferous tubules. Scale bars represent $40 \mu \mathrm{m}$.

\section{Immunocytochemistry}

Immunoreactivity for the inhibin $\alpha$ and inhibin/activin $\left(\beta_{\mathrm{A}}\right.$ and $\beta_{\mathrm{B}}$ ) subunits was present in the testes during the breeding and nonbreeding seasons, respectively (Fig. 4). Inhibin $\alpha$ and inhibin/ activin $\left(\beta_{\mathrm{A}}\right.$ and $\beta_{\mathrm{B}}$ ) subunits were present in the cytoplasm of Leydig cells and Sertoli cells in the breeding season during May (Fig. $4 \mathrm{a}, \mathrm{b}$ and $\mathrm{c}$ ). The inhibin $\alpha$ and inhibin/activin $\beta_{\mathrm{B}}$ subunits were expressed in the cytoplasm of Sertoli cells but not in undifferentiated interstitial cells in the non-breeding season during September (Fig. 4d and f). The intensities of the immunohistochemical signals for the inhibin $\alpha$ and inhibin/activin $\beta_{\mathrm{B}}$ subunits appear to differ between the non-breeding and breeding seasons. More intense immunostaining was observed for the inhibin $\alpha$ and inhibin/activin $\beta_{\mathrm{B}}$ subunits in the breeding season, respectively (Fig. 4a and c). Immunoreactivity was not observed for the inhibin $\alpha$ and inhibin/ activin $\left(\beta_{\mathrm{A}}\right.$ and $\left.\beta_{\mathrm{B}}\right)$ subunits in germ cells in the non-breeding and breeding seasons. No immunostaining was detected in control sections when normal rabbit serum was substituted for the primary antibody (Fig. 4g).

\section{Discussion}

The results of the present study demonstrate that testicular tissues are the cellular source of inhibin and that seasonal changes in the distribution of inhibin subunits $\alpha, \beta_{\mathrm{A}}$ and $\beta_{\mathrm{B}}$ are accompanied by changes in spermatogenesis that are correlated with changes in testicular weight and size and diameter of the seminiferous tubule in the wild ground squirrel. These findings suggest that ground squirrel testes produce inhibin not only in the breeding season but also in the non-breeding season and that inhibin may be useful as a marker of testicular function in the wild ground squirrel.

The distribution of inhibin subunits in the normal adult male corresponds to the sites of production of inhibins and activins in the context of mature Sertoli cells and normal spermatogenesis [21]. Identification of the sites of expression and production of inhibin subunit messenger RNA and protein is critical to understanding the biology of inhibins [21]. In the present study, the inhibin $\alpha$ and inhibin/activin ( $\beta_{\mathrm{A}}$ and $\beta_{\mathrm{B}}$ ) subunits were expressed in testicular tissues of the ground squirrel during the breeding season, showing

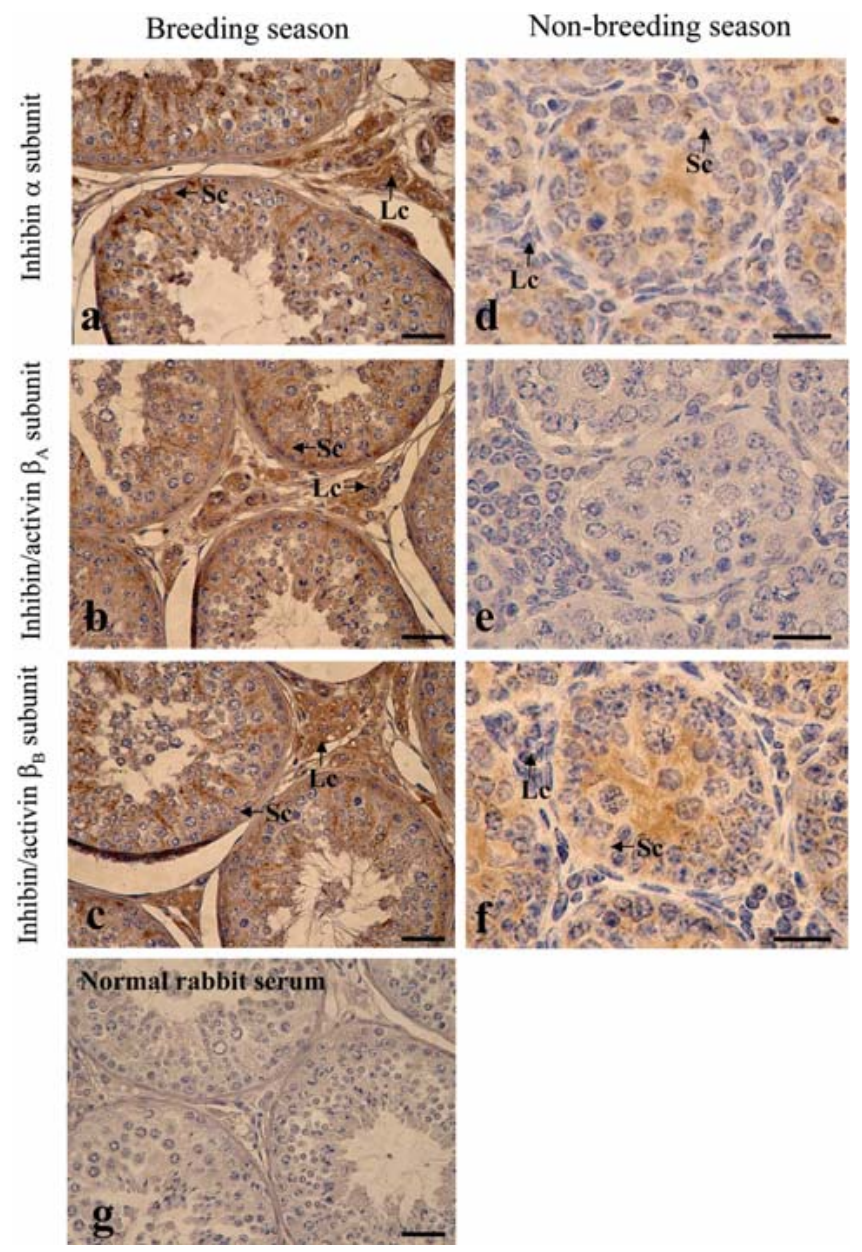

Fig. 4. Immunolocalization of the inhibin $\alpha$ and inhibin/activin $\left(\beta_{\mathrm{A}}\right.$ and $\beta_{\mathrm{B}}$ ) subunits in the testes of the wild ground squirrel in the breeding (a, b, c; May) and non-breeding seasons (d, e, f; September). Immunostaining was found for the inhibin $\alpha$ (a), inhibin/activin $\beta_{\mathrm{A}}(\mathrm{b})$ and inhibin/activin $\beta_{\mathrm{B}}$ (c) subunits in Leydig cells (Lc) and Sertoli cells (Sc) in the breeding season. Immunostaining for the inhibin $\alpha$ (d) and inhibin/activin $\beta_{\mathrm{B}}(\mathrm{f})$ subunits was only present in Sertoli cells in the non-breeding season. Immunostaining was not found for the inhibin/activin $\beta_{\mathrm{A}}$ subunit (e) in testicular tissues in the non-breeding season. Immunoreactivity was not found for the inhibin $\alpha$ and inhibin/ activin ( $\beta_{\mathrm{A}}$ and $\beta_{\mathrm{B}}$ ) subunits in germ cells in the non-breeding and breeding seasons. No immunostaining was detected in control sections in which normal rabbit serum was substituted for the primary antibody (g). Scale bars represent (a, b, c, g) $80 \mu \mathrm{m}$ and (d, e, f) $50 \mu \mathrm{m}$.

that testicular tissues may secrete dimeric and bioactive activins and inhibins in the breeding and non-breeding seasons. These findings are not unique to the ground squirrel, as similar observations have been found in other seasonal breeders, such as rams [22], Japanese black bears [14], raccoon dogs [15] and stallions [23]. In rams, the presence of all three inhibin/activin subunits in adult testes has been confirmed for mRNA by northern blot analysis and for protein by immunocytochemistry, showing that the testes could produce and secrete dimeric inhibin during the reproductive cycle 
[22]. In Japanese black bears and raccoon dogs, inhibin $\alpha, \beta_{\mathrm{A}}$ and $\beta_{\mathrm{B}}$ subunit positive staining was observed in both Sertoli and Leydig cells in the breeding season, suggesting that the Sertoli and Leydig cells of black bears could secrete bioactive inhibins in the breeding season [14, 15]. Previous studies have suggested that inhibin subunits may play some important roles in spermatogonial development [24, 25], Sertoli cell proliferation [26] and steroid biosynthesis [26-29]. Recent studies in the ground squirrel have also demonstrated that P450arom is present in the Leydig and Sertoli cells in the breeding season, indicating that the Leydig and Sertoli cells of the ground squirrels have the ability to secrete testosterone and estradiol (Qiang Weng, unpublish results). These results indicate that the production of inhibin, and possibly activin, is dependent on the stage of the cycle of the seminiferous epithelium; these growth factors might cooperate with steroid hormones and play a paracrine role in differentiation of spermatogenic cells. The present study clearly showed that inhibin $\alpha$ and inhibin/activin $\left(\beta_{\mathrm{A}}\right.$ and $\beta_{\mathrm{B}}$ ) were not detected in the Leydig cells of the ground squirrel in the non-breeding season but were observed in Leydig and Sertoli cells in the breeding season. Leydig cells have previously been shown to be able to produce inhibin in vitro in response to stimulation by LH [30]. They may also be involved in a paracrine or autocrine role locally within the testis in regulating inhibin production by Sertoli cells [31]. In recent studies, the expression of inhibin subunits and secretion of protein has displayed a stage-specific pattern within the seminiferous epithelium in both Sertoli cells and germ cells [32-34]. The Sertoli cell is generally regarded as the principal site of inhibin production in the testes as initially demonstrated by the secretion of inhibin by Sertoli cells in vitro [35]. Therefore, our results showing that the inhibin $\alpha, \beta_{\mathrm{A}}$ and $\beta_{\mathrm{B}}$ subunits are present in Leydig and Sertoli cells during the breeding season support the postulation that, although Sertoli cells do not increase in number in the breeding season [36, 37], their capacity for protein secretion (for example, androgen binding protein and inhibin) and for support of increased numbers of germ cells, as in spermatogenesis, becomes more efficient [38].

In rats, hamsters and humans, inhibin B is the predominant form in the testis [39-41]. Inhibin B levels are positively correlated with Sertoli cell function, sperm number and spermatogenic status and are negatively correlated with FSH. It appears that regulation of inhibin B production is mediated by a complex interaction between FSH, Sertoli cells, Leydig cells and germ cells [21]. In the present study, immunoreactivity specific to inhibin $\beta_{\mathrm{B}}$ subunit was observed in both the breeding and non-breeding seasons, but the inhibin $\beta_{\mathrm{A}}$ subunit was found in only the breeding season. Future studies will investigate seasonal changes in the plasma concentrations of inhibins and clarify which inhibin form is important for spermatogenesis in wild ground squirrels. In summary, the present results demonstrated that seasonal changes in testicular weight and size and seminiferous tubule diameter in wild ground squirrels are correlated with changes in spermatogenesis and the testicular distribution of inhibin/activin subunits. The data presented here will greatly aid in determination of the inhibin/activin endocrine pathways in wild ground squirrels, the animal model of choice for studying testicular recrudescence and regression.

\section{Acknowledgements}

We wish to express our gratitude to Dr. C. Amaya-Montoya (Laboratory of Veterinary Physiology, Department of Veterinary Medicine, Faculty of Agriculture, Tokyo University of Agriculture and Technology, Fuchu, Tokyo, Japan) for reading the original manuscript and for his valuable suggestions. The authors are grateful to Dr. N. Ling (Neuroendocrine, San Diego, CA, USA), for providing [Tyr30] inhibin- $\alpha-(1-30)$ and to Dr. W. Vale (Clayton Foundation for Peptide Biology, Salk Institute for Biological Studies, La Jolla, CA, USA), for providing antisera against the inhibin $\beta_{\mathrm{A}}$ and $\beta_{\mathrm{B}}$ subunits. This study was supported in part by a Grantsin-Aid for The Innovative Experiment Projects for National Undergraduates (GCS07029) from the Ministry of Education of China and the Program for Changjiang Scholars and Innovative Research Team in Universities (IRT0607) from China and a Grants-in-Aid for Scientific Research (Basic Research B-18310044, P06445) from the Japan Society for the Promotion of Science.

\section{References}

1. Lin T, Calkins JK, Morris PL, Vale W, Bardin CW. Lin T, Calkins JK, Morris PL Vale W, Bardin CW. Regulation of Leydig cell function in primary culture by inhibin and activin. Endocrinology 1989; 125: 2134-2140.

2. Chen CL. Inhibin and activin as paracrine/autocrine factors. Endocrinology 1993; 132 4-5.

3. Mather JP, Moore A, Li RH. Activins, inhibins, and follistatins: further thoughts on a growing family of regulators. Proc Soc Exp Biol Med 1997; 215: 209-222.

4. Burger HG, Igarashi M. Inhibin: definition and nomenclature, including related substances. Mol Endocrinol 1988; 2: 391-392.

5. Tanaka $Y$, Taniyama $H$, Tsunoda $N$, Shinbo $H$, Nagamine $N$, Nambo $Y$, Nagata $S$, Watanabe G, Herath CB, Groome NP, Taya K. The testis as a major source of circulating inhibins in the male equine fetus during the second half of gestation. J Androl 2002, 23: 229-236.

6. Bhasin S, Krummen LA, Swerdloff RS, Morelos BS, Kim WH, diZerega GS, Ling N Esch F, Shimasaki S, Toppari J. Stage dependent expression of inhibin alpha and beta-B subunits during the cycle of the rat seminiferous epithelium. Endocrinology 1989; 124: 987-991.

7. Klaij IA, van Pelt AM, Timmerman MA, Blok LJ, de Rooij DG, de Jong FH. Expression of inhibin subunit mRNAs and inhibin levels in the testes of rats with stage-synchronized spermatogenesis. J Endocrinol 1994; 141: 131-141.

8. Nagata S, Tsunoda N, Nagamine N, Tanaka Y, Taniyama H, Nambo Y, Watanabe G, Taya K. Testicular inhibin in the stallion: cellular source and seasonal changes in its secretion. Biol Reprod 1998; 59: 62-68.

9. Nagata S, Miyake YI, Nambo Y, Nagamine N, Watanabe G, Tsunoda N, Taniyama H, Hondo E, Yamada J, Taya K. Inhibin secretion in the stallion. Equine Vet J 1998; 30: 98-103.

10. Lincoln GA, McNeilly AS. Inhibin concentrations in the peripheral blood of rams during a cycle in testicular activity induced by changes in photoperiod or treatment with melatonin. J Endocrinol 1988; 120: 9-13.

11. Zhang T, Zhou HM, Liu YX. Expression of plasminogen activator and inhibitor, urokinase receptor and inhibin subunits in rhesus monkey testes. Mol Hum Reprod 1997; 3: 223-231.

12. Matsubayashi K, Watanabe G, Taya K, Katakai Y, Sasamoto S, Suzuki J, Nozaki M Seasonal changes in plasma concentrations of immunoreactive inhibin and testicular activity in male Japanese monkeys. Biol Reprod 1991; 44: 822-826.

13. Itoh M, Kondo M, Kojima C, Jin W, Watanabe G, Taya K, Hayashi M, Shimizu K Inhibin $B$ is the major form of inhibin secreted from testes in male Japanese macaques (Macaca fuscata). Primates 2003; 44: 253-257.

14. Weng Q, Medan MS, Okano T, Murase T, Tsubota T, Xu M, Watanabe G, Taya K Changes in serum inhibin levels and immunolocalization of inhibin/activin subunits during the breeding season in the wild male Japanese black bear (Ursus thibetanus japonicus). Endocrine 2006; 29: 345-350.

15. Weng $\mathbf{Q}$, Medan MS, Xu M, Tsubota T, Watanabe G, Taya K. Seasonal changes in immunolocalization of inhibin/activin subunits and testicular activity in wild male raccoon dogs (Nyctereutes procyonoides). J Reprod Dev 2006; 52: 503-510. 
16. Pudney J, Canick JA, Clifford NM, Knapp JB, Callard GV. Location of enzymes of androgen and estrogen biosynthesis in the testis of the ground squirrel. Biol Reprod 1985; 33: 971-980.

17. Nunes S, Pelz KM, Muecke EM, Holekamp KE, Zucker I. Plasma glucocorticoid concentrations and body mass in ground squirrels: seasonal variation and circannual organization. Gen Comp Endocrinol 2006; 146: 136-143.

18. Holekamp KE, Talamantes F. Seasonal variation in circulating testosterone and oestrogens of wild-caught California ground squirrels. J Reprod Fertil 1991; 93: 415425 .

19. Vaughan JM, Rivier J, Corrigan AZ, McCLintock R, Jolley D, Voglmayr JK, Bardin CW, Rivier C, Vale W. Detection and purification of inhibin using antisera generated against peptide fragments. Method Enzymol 1989; 168: 588-617.

20. SAS. Statistics, version 6.11, Cary, NC: SAS Institute. 1987

21. O'Connor AE, De Kretser DM. Inhibins in normal male physiology. Semin Reprod Med 2004; 22: 177-185.

22. McNeilly AS, Souza CJ, Baird DT, Swanston IA, McVerry J, Crawford J, Cranfield M, Lincoln GA. Production of inhibin A not B in rams: changes in plasma inhibin A during testis growth, and expression of inhibin/activin subunit mRNA and protein in adult testis. Reprod 2002; 123: 827-835

23. Nagata S, Tsunoda N, Nagamine N, Tanaka Y, Taniyama H, Nambo Y, Watanabe G, Taya K. Testicular inhibin in the stallion: cellular source and seasonal changes in its secretion. Biol Reprod 1998; 59: 62-68.

24. Van Dissel-Emiliani FM, Grootenhuis AJ, de Jong FH, de Rooij DG. Inhibin reduces spermatogonial numbers in testes of adult mice and Chinese hamsters. Endocrinology 1989; 125: 1899-1903.

25. Mather JP, Attie KM, Woodruff TK, Rice GC, Phillips DM. Activin stimulates spermatogonial proliferation in germ-Sertoli cell cocultures from immature rat testis. Endocrinology 1990; 127: 3206-3214.

26. Boitani C, Stefanini M, Fragale A, Morena AR. Activin stimulates Sertoli cell proliferation in a defined period of rat testis development. Endocrinology 1995; 136: 54385444

27. Hsueh AJ, Dahl KD, Vaughan J, Tucker E, Rivier J, Bardin CW, Vale W. Heterodimers and homodimers of inhibin subunits have different paracrine action in the modulation of luteinizing hormone-stimulated androgen biosynthesis. Proc Natl Acad Sci 1987; 84: 5082-5086.

28. Mauduit C, Chauvin MA, de Peretti E, Morera AM, Benahmed M. Effect of activin A on dehydroepiandrosterone and testosterone secretion by primary immature porcine Leydig cells. Biol Reprod 1991; 45: 101-109.
29. De Winter JP, Vanderstichele HM, Timmerman MA, Blok LJ, Themmen AP, de Jong FH. Activin is produced by rat Sertoli cells in vitro and can act as an autocrine regulator of Sertoli cell function. Endocrinology 1993; 132: 975-982.

30. Risbridger GP, Clements J, Robertson DM, Drummond AE, Muir J, Burger HG, de Kretser DM. Immuno- and bioactive inhibin and inhibin alpha-subunit expression in rat Leydig cell cultures. Mol Cell Endocrinol 1989; 66: 119-122.

31. Tena-Sempere M, Kero J, Rannikko A, Yan W, Huhtaniemi I. The pattern of inhibin/activin alpha- and betaB-subunit messenger ribonucleic acid expression in rat testis after selective Leydig cell destruction by ethylene dimethane sulfonate. Endocrinology 1999; 140: 5761-5770.

32. Buzzard JJ, Farnworth PG, De Kretser DM, O'Connor AE, Wreford NG, Morrison JR. Proliferative phase sertoli cells display a developmentally regulated response to activin in vitro. Endocrinology 2003; 144: 474-483.

33. Klaij IA, van Pelt AM, Timmerman MA, Blok LJ, de Rooij DG, de Jong FH. Expression of inhibin subunit mRNAs and inhibin levels in the testes of rats with stage-synchronized spermatogenesis. J Endocrinol 1994; 141: 131-141.

34. Gonzales GF, Risbridger GP, Hodgson YH, Pollanen P, de Kretser DM. Stage-specific inhibin secretion by rat seminiferous tubules. Reprod Fertil Dev 1989; 1: 275-279.

35. Le Gac F, de Kretser DM. Inhibin production by Sertoli cell cultures. Mol Cell Endocrinol 1982; 28: 487-498.

36. Jin W, Herath CB, Yoshida M, Arai KY, Saita E, Zhanquan S, Ren L, Watanabe G, Groome NP, Taya K. Inhibin B regulating follicle-stimulating hormone secretion during testicular recrudescence in the male golden hamster. J Androl 2002; 23: 845-853.

37. Hochereau-de Reviers MT, Monet-Kuntz C, Courot M. Spermatogensis and Sertoli cell numbers and function in rams and bulls. J Reprod Fertil 1987; 34 (Suppl): 101-114.

38. Sanford LM, Price CA, Leggee DG, Baker SJ, Yarney TA. Role of FSH, numbers of FSH receptors and testosterone in the regulation of inhibin secretion during the seasonal testicular cycle of adult rams. Reproduction 2002; 123: 269-280.

39. Buzzard JJ, Loveland KL, O'Bryan MK, O'Connor AE, Bakker M, Hayashi T, Wreford NG, Morrison JR, de Kretser DM. Changes in circulating and testicular levels of inhibin A and B and activin A during postnatal development in the rat. Endocrinology 2004; 145: 3532-3541.

40. Illingworth PJ, Groome NP, Byrd W, Rainey WE, McNeilly AS, Mather JP, Bremner WJ. Inhibin-B: a likely candidate for the physiologically important form of inhibin in men. J Clin Endocrinol Metab 1996; 81: 1321-1325.

41. Jin W, Wada S, Arai KY, Kishi H, Herath CB, Watanabe G, Suzuki AK, Groome NP, Taya K. Testicular secretion of inhibin in the male golden hamster (Mesocricetus auratus). J Androl 2000; 22: 207-211. 